\title{
46. How Loos-en-Gohelle, a derelict mining town in the north of France, has become a standard in sustainable development
}

\section{Michel Berry}

Jean-François Caron was elected mayor of Loos-en-Gohelle in 2001 as a member of the Green Party. An election on this ticket is very unusual in the Nord-Pas-de-Calais region, a mining area that used to employ as many as 220000 people. He succeeded his father as mayor, and this, in the world of 'mining paternalism', gave him a sort of endorsement. Previously, Caron had also been in charge of an important group project aimed at developing the town. These unique circumstances set the stage for one of the most surprising transformations of a town and a region ever seen. ${ }^{1}$

\section{BOUNCE BACK OR DIE}

Jean-François Caron likes to say that he represents the generation of beneficiaries of 'non-sustainable development'. Initially, a great deal of wealth was created in the mining area, but when the mines closed the inhabitants had to deal with the after-effects. When he was elected mayor, the level of nitrates in the water tables was twice the amount permitted by the French government (99 $\mathrm{mg}$ per litre compared to $50 \mathrm{mg}$ ), and there had been a subsidence of up to 15 metres as a result of mining (Loos had nine pits in its region). The streams ran in the opposite direction to their original courses, and the low levels of the town kept changing. The surrounding countryside was spoiled because its sole purpose had been to service industrial activity for which the region and the population were merely adjustment variables.

Added to this, the population had a large identity problem. For a very long period of time, the miners had been the jewel in the working-class crown, but when the mines closed the inhabitants of the Nord-Pas-de-Calais became known as the 'freaks of France'. In 2008, in Paris, at a football cup final at the Parc des Princes stadium, there was a banner saying 'Northerners = half-bloods, paedophiles, alcoholics'. When the media latched on to this, it 
merely reinforced the negative image, which the mining town inhabitants found unbearable. From that moment onwards, whenever a television journalist made a documentary about Northern France, it featured people who spoke the local dialect (and therefore it was decided that the viewer needed subtitles), children whose noses were running, and broken window panes. Repairing this lost dignity was an essential part of the new mayor's strategy.

Furthermore, the mining population had been living for a long period of time in a state of submission. Nine geographical groups incorporated nationalized mines in Northern France known as 'Les Houillères'. Each group had its own maternity unit, stadium, churches, housing, associations, and social security offices, with the exception of cemeteries. A miner was liable to lose part of his salary if he did not maintain his garden, as gardening was judged to be a beneficial activity, because if a miner was gardening he was not in the local bistrot or trade union office. Central mining cooperatives issued families with booklets of coupons, and each purchase made using these booklets was immediately deducted from the miner's salary. These extreme conditions ensured a compliant population who found it difficult to adapt to changes in society.

A number of political and administrative strategies were put forward. Some considered reducing the size of the local population by moving inhabitants to Fos-sur-Mer, for example, a steel and oil industry site in the south of France. Thousands of people relocated there, but this did not solve the problem in the north. Other strategies of reindustrialization - for example, promoting the car industry - were implemented in order to reproduce events from the region's industrial past, but this was not in keeping with the region's mining history.

As far as Jean-François Caron was concerned, they either had to bounce back, or go under. Loos-en-Gohelle was the first town in the Nord-Pas-de-Calais region to see the situation from a different angle. Caron was convinced that the way forward for the town and the region (of which he was also vice-president) was with renewable energy and the internet. He organized conferences about employment possibilities to explain the details of these future changes. He had been working with Jeremy Rifkin ${ }^{2}$ since 2010 . Rifkin's plans were in step with the Nord-Pas-de-Calais region's ideas, which declared that renewable energy and optimized management of production and consumption, with local loops, had to be at the heart of the new model, which is less driven by production and is more economic in terms of energy. The model also stated that those involved with the development of public policy had to be fully integrated into this movement.

However, this new model and the path necessary to achieve it were not yet clear. How could one convince a population, which was used to being helped and which lacked self-confidence, to try to develop its own future? Jean-François Caron devised an approach based on three priorities: involving the inhabitants; enhancing the mining heritage; and using 'applied' renewable 
energy. In other words, adopting an experimental approach that allowed for errors.

\section{DEMOCRACY INVOLVING THE POPULATION}

Since his election as mayor, Caron has been working on perfecting a concept of democracy in which the population of Loos was truly involved. This approach is different from the model of 'participative democracy' (which has become increasingly fashionable in France) whereby people are asked for their opinions, and what they want, leaving politicians to decipher the population's 'wish list'. In this situation, everyone loses out, as all the needs are naturally impossible to meet: citizens become frustrated as they feel that their requests have not been heard, and policies are undermined as they appear to have betrayed the citizens. Democracy where the population is involved consists instead of organizing meetings on subjects that directly concern the population, letting the citizens express their wishes and recriminations, and then discussing possible solutions with them, and, above all, getting them involved in the process.

Setting this up is slow and requires patience. Jean-François Caron advises his teams about how to handle the first half-hour of these meetings and to say nothing while people get their complaints off their chests. After this, it is possible to talk about more concrete problems, and to begin a constructive process. In the long run, this process has surprising results, and the inhabitants can become clear about numerous subjects, and even be rude. As Jean-François Caron writes: 'the more we work with our citizens, the more their feedback helps us improve the process, and the more pertinent the projects become. This is how Loos has become noted in the product-service and cooperation system due to its ability to be close to its citizens and processes and to find a series of solutions'.

The number of social associations has doubled, and the number of people taking part in neighbourhood celebrations or in trips for local children to discover the seaside has multiplied tenfold. '50-50' joint projects have been put in place; in other words, if the inhabitants take initiatives, the town contributes by creating a charter defining the roles. For example, Loos town hall built a children's educational garden, but it is the parents' or grandparents' responsibility - and not the municipality's - to maintain the garden. Also, a skatepark was designed and built with help and input from teenagers, encouraging them to become aware about regulatory matters and to appreciate the costs of such a project. Farm roads have been resurfaced with help from local farmers who supplied the skips to transport the construction waste. Since then, the farmers have been more careful to avoid making ruts in the roads they use. The main idea behind these actions is that, in change management, the 'soft' side, with 
its psycho-sociological dimensions, is more important than the 'hard', technological side, and that involvement in taking action is a powerful motor for triggering the process of change.

\section{ENHANCING THE MINING HERITAGE}

In the 1980s, the authorities who had taken the decision to close the pits wanted to make all trace of them disappear. According to Jean-François Caron, this marked a period of rejecting the region's history when some people even said they were sorry for having existed. Loos refused to take this point of view and declared that one could not build any future if one denied one's past. Many of Loos' inhabitants have Polish, Hungarian or North African surnames, and the mines played a crucial role in their lives and the construction of their identities. Telling them that they were now the 'wretched of the Earth' and nobodies, while at the same time telling them to be creative and enterprising, would have been pointless. On the contrary, 'we realized that we had to enhance our past in order to plan for the future'. This was the thinking behind the creation in 1984 of a series of storytelling and 'sound and light' shows called the 'Gohelliades', based on the theme 'The People and Riches of the Gohelle region - Land and Industry - Art and Tradition'. ${ }^{3}$

In Loos, there were two large slag heaps that some officials had wanted to eradicate. The municipality of Loos replied that these were wonderful slag heaps, the highest in Europe at 146.50 metres, the same height as the Great Pyramid of Giza: 'if we marvel at the Egyptian pyramids, why should we look down on these symbols of human-made activity?' This remark was the starting point for the creation of the 'The Chain of Slag Heaps', an association that, in 2012, resulted in the coal-mining region's inclusion in UNESCO's list of World Heritage sites.

Long before he became mayor, Jean François Caron was interested, with other young people in Loos, in the revitalization of these slag heaps, remarking that very interesting flora and fauna had been found specifically in this industrial area. Subsequently, in 1987, they created the 'Association des Naturalistes de la Gohelle', whose role was to persuade the département to pass biotope legislation making people change the way in which they looked at the slag heaps and then trying to save them. When Jean-François Caron became mayor, he decided to make the heaps more accessible physically and organised activities in order to discover the flora and fauna. He also wanted to integrate them into a new urban park that, like the slag heaps themselves, would enhance the image of the mining area.

The 11/19 Pit, at the foot of the slag heaps, was 1000 metres deep. It was renamed Base 11/19 and became the site of the new model for economic development. Alongside, new associations emerged, including 'The Chain 
of Slag Heaps', which protects the mining heritage and its biodiversity, and 'Common Culture', an association encouraging artistic creation and shows. In 2002, Jean-François Caron encouraged the development of the 'Creation of the Development of Eco-enterprises $(\mathrm{Cd} 2 \mathrm{e})$ association. He realized that 'the region receives a great deal of money in order to restore its degraded environment; however, the area does not have companies which can meet such needs. Therefore, we should create a system of "group intelligence", organizing technological, technical and legal monitoring, and locating research laboratories in the region'.

\section{SUSTAINABLE DEVELOPMENT}

The Cd2e association's primary concern is to promote eco-construction and eco-materials with two objectives: first, to assist and promote companies; and second, to advise local authorities and help construction projects. Over the years, the association has expanded its aid into the water and energy sectors, and even the circular economy. It currently employs about 20 people and has at its disposal a list of more than 500 regional companies that are in eco-construction and 150 in eco-materials.

There is a 'theatre of eco-materials' available as a form of demonstration to professionals (such as architects, consultants and company managers), and also to researchers and the general public who can come to discover and touch the basic materials of eco-construction. The 'Apprentis d'Auteuil' association, which helps to integrate young people into society, has opened a training facility in Loos for 350 apprentices in the eco-construction sector. LumiWatt, a platform for the development of photovoltaic activities in zones of moderate sunshine, is testing about 30 innovative technologies in collaboration with various engineering and architecture schools in the region.

Because miners did not have to pay for the coal to heat their homes, insulation was not a major concern. It has now become extremely expensive to heat their homes because of fuel costs. Eco-construction and thermal retrofitting have therefore become a priority, and the inhabitants of renovated accommodation can easily tell the difference with regard to their previous expenses and living conditions, and this, of course, is a powerful tool for change. All social housing in Loos will have to be built according to the rules of eco-construction. This amounts to about 10 per cent of all housing in Loos; in other words, between 250 and 300 eco-built and eco-fitted forms of accommodation.

In ten years, the 11/19 site has been totally transformed. While enhancing its historical heritage, the town of Loos-en-Gohelle has taken up the challenge of economic renewal by making the Base 11/19 a flagship zone for sustainable development in the Nord-Pas-de-Calais region. 
Transformation has been taking place on all fronts. Water costs twice the average price in France even though it was twice as polluted as anywhere else. Over the past 15 years, all municipal buildings have been fitted with rainwater storage systems, and no drinking water whatsoever is used by municipal services. Thanks to rainwater harvesting, Loos can now go without water for three weeks as a result of its municipal watering, cleaning and sanitation requirements. Even though the price of water has not yet changed (it is fixed by a public service delegation and is based on the scale of the metropolitan area that includes several towns), consumption for municipal use has dropped considerably.

The town wants to develop a new agricultural and foodstuffs model. An initial reason for action is to supply school canteens in Loos and its surrounding area with organic products. To do so, the town is developing short-circuits in order to purchase directly from local growers. Five of them have already changed to organic farming. Their farming area represents 10 per cent of the town's total area, compared to 4 per cent as a national average. Loos is also working with school caterers to create meals requiring them, for example, to use a vegetable-processing plant to handle local produce and not to be supplied by large food manufacturers.

Loos has been called 'the town with the solutions' and was cited as a reference at the UN COP21 climate change conference. The terrorist attacks in Paris on 13 November 2015 unfortunately cancelled the scheduled meeting at Loos of 500 high-ranking civil servants from all over the world. Nonetheless, Loos' experience has received a great deal of media attention, and Jean-François Caron has become known in energy, ecological and social transition circles. He now wants to go a stage further and change scale.

\section{CHANGING SCALE}

A virtuous circle was created at Loos: feelings of trust encouraged group initiatives, and these in turn led to results that maintained and bolstered the level of trust. Apart from questions about ecology and sustainable development, the process that has been implemented has had beneficial effects on good manners. There is no damage or degradation to urban property, unlike in neighbouring towns, and the number of lawsuits between neighbours has also greatly diminished. Jean-François Caron was re-elected mayor in 2008 with a majority of 82.1 per cent, and again in 2014 with 100 per cent: a first for a politician, and a dream come true for an ecologist! This is even more surprising in the light of the fact that just a few kilometres from Loos in another mining town, Hénin-Beaumont, a National Front mayor was elected. This juxtaposition highlights the contrast in the ability of the people in one town to live together in a climate of trust, and in a nearby town, for its inhabitants to have 
feelings based on distrust. Despite this, a number of people in neighbouring towns and villages have begun to adopt the same methods that are in place in Loos-en-Gohelle. Mayors come to meet Jean-François Caron to ask him for advice about managing an 'eco-district', carrying out renewable energy strategies, developing eco-materials, creating food short-circuits, or even putting together the necessary specifications for calls for tender. The greatest number of requests concerns how to put participatory processes in place.

Sharing their experience is now the challenge for the Loos teams. A major difficulty, however, is that one cannot simply copy the solutions that have been put in place at Loos, because each region has its own history, resources, traditions and specific means of organizing its executive.

The way forward in terms of action to be taken emerged from work with the research intervention laboratory, Analyse du Travail et des Mutations dans l'Industrie et les Services (ATEMIS), and a person in charge of telling the story of the town's transformation. We can refer to it as the operation's 'source code'. Just like in open source, lines of code cannot be copied word for word, but serve as a basis for writing one's own, unique version. The key elements of this source code are:

- involving the inhabitants, which requires teaching team members and time;

- finding a 'shining star', a reference that encourages everyone to move forward to reach the goals achieved by this star, and to put down markers to chart the way forward (such as roofing the town's church with solar panels, or suppling organic meals for school canteens, etc.);

- addressing problems in a systemic way, which means fundamentally changing management methods used by the municipal team, which itself is ordinarily strictly separated into specific areas; and

- encouraging people to think 'outside the box', and go against one-track thinking, but without panicking the inhabitants: for example, making a slag heap a work of art was a necessary transgression to move forward.

Once the source code was formalized, the Agence de l'environnement et de la maîtrise d'énergie (ADEME) ${ }^{4}$ was able to evaluate the town as a 'national demonstrator of changing management methods' with the aim of creating a sustainable city. Then, the source codes for Loos were compared to those of three other pilot towns, Grande Synthe (near Calais), Malaunay (in Normandy) and Le Méné (in Brittany).

Because these source codes were consistent, a project emerged. In order to refine the guidelines for action to be taken in very different contexts, a new workshop was created that brought together about 15 regions as diverse as the City of Paris (with its 'resilience strategy' and group of elected representatives responsible for the environment), L'Île-Saint Denis (part of the Plaine 
Commune area), Montreuil, and the city of Caen (with the intermediary of a district transition group). This workshop is a sort of 'transitions exercise gym' where small and large regions can discuss how it is possible to manage best subsidiarity (where issues are dealt with at the most immediate or local level) and cooperation on various scales in the different and multi-layered regional frameworks. This work between regions, which are on a par, is of interest to a wide range of people, including elected representatives, officers and entrepreneurs.

A 'Third Space' has now been launched to bring together state-run institutions, authorities, companies, transition networks, consultancies and think-tanks, in order to develop a so-called 'Transitions Factory' on a national level.

Several regions are now working together to devise ways in which transition can take place as a sharing process rather than according to a 'top-down' process that is very popular in France. Drawing on local specificities and bringing together local people seems to be the most certain way to involve everyone in the process of ecological transition.

\section{NOTES}

1. This chapter comes from J.-F. Caron's talk at the École de Paris du management on 13 May 2016 entitled 'Can the unique success of Loos-en-Gohelle be repeated elsewhere?', and from J. Denantes' (2019) report in La Jaune et la Rouge, No. 749 , pp. 82-85, entitled "Un entrepreneur de territoire dans le bassin houiller du Pas-de-Calais", accessed 19 August 2020 at https://www.lajauneetlarouge.com/ wp-content/uploads/2019/10/La_jaune_et_la_rouge_749_82-85.pdf.

2. Jeremy Rifkin is an American economic and social theorist writer, public speaker, political advisor and activist. He is the author of 21 books about the impact of scientific and technological changes on the economy, the workforce, society, and the environment.

3. The 'Gohelle' region is a small, traditional area in the Pas-de-Calais département in Northern France. Its centre is the city of Lens (4 km from Loos). For the most part, it is a low-lying, large floodplain with different strata of rocks (sandstone, schist and limestone). There are numerous seams of coal that were full of shafts and very deep tunnels (several hundreds of metres deep) during the industrial era and until the end of the twentieth century, as in the entire mining area of the Nord-Pas-de-Calais region to which Gohelle belongs.

4. ADEME is a public agency that takes part in the implementation of public policy in the sectors of the environment, energy and sustainable development. It offers companies, local authorities, public authorities and the general public expertise and advice. Furthermore, it helps to finance projects and research for implementing projects in its fields of activity. It has more than 1000 staff. 